\title{
Miejsce bezpieczeństwa osobowego w systemie ochrony informacji niejawnych
}

\section{Wstęp}

Współcześnie informacja ma niepodważalne znaczenie dla wielu dziedzin życia zarówno prywatnego, jak i publicznego. W celu zapewnienia właściwego funkcjonowania państwa i jego bezpieczeństwa bardzo często musi być ona należycie chroniona. Taką ochronę gwarantuje się m.in. poprzez nadanie informacjom odpowiedniej klauzuli tajności. Nadając taką klauzulę ze względu na okoliczności zagrażające bądź mogące zagrozić bezpieczeństwu państwa, ustawodawca wyłącza zasadę jawności działania władzy publicznej, w związku z czym wnioskodawca nie może skutecznie domagać się udostępnienia tak zabezpieczonych informacji.

Nieuprawnione ujawnienie informacji chronionych odpowiednią klauzulą tajności godzi (jak również może godzić) w interesy nie tylko państwa, ale też i społeczeństwa, powodując (jak i mogąc powodować) szkody w przestrzeni zarówno publicznej czy gospodarczej, jak i społecznej. W przypadku ochrony informacji niejawnych ważne są nie tylko odpowiednie narzędzia ochrony — nie do przecenienia jest również aspekt personalny. Osoba, która ma dostęp do tego rodzaju informacji, musi dawać rękojmię zachowania tajemnicy, a uprawnienia te posiada wyłącznie w zakresie niezbędnym do wykonywania przez nią pracy lub pełnienia służby na zajmowanym stanowisku bądź też w zakresie niezbędnym do wykonywania czynności zleconych. Bezpieczeństwo osobowe w sferze ochrony informacji niejawnych będzie miało więc podstawowe znaczenie z punktu widzenia bezpieczeństwa państwa - zagrożeń zarówno militarnych, jak i niemilitarnych.

Wśród procedur określanych mianem instrumentów bezpieczeństwa szczególną rolę należy przypisać postępowaniu sprawdzającemu. Rola ta wynika z faktu, 
że osoby poddane tej procedurze zajmują stanowiska związane $\mathrm{z}$ dostępem do informacji objętych stosowną klauzulą tajności. Będzie to zatem, z racji ochrony interesów bezpieczeństwa państwa, „wybrana” grupa osób, na której ze względu na obowiązki służbowe ciążą szczególne powinności ${ }^{1}$. Reżim prawny przewidziany w kwestii dostępu do informacji objętych klauzulą co najmniej „poufne”, w tym konieczność przeprowadzenia postępowania sprawdzającego i uzyskania poświadczenia bezpieczeństwa, służy ochronie informacji niejawnych, a jego ogólnym, a zarazem podstawowym celem jest bezpieczeństwo państwa.

\section{Dostęp do informacji niejawnych}

Ze względu na status informacji niejawnych, w tym ich znaczenie dla bezpieczeństwa państwa, istnieje konieczność ich ochrony. W związku z tą ochroną dopuszczenie do pracy lub pełnienia służby na stanowiskach, na których niezbędny staje się dostęp do informacji niejawnych, bądź też zlecenie prac związanych z dostępem do takich informacji, które oznaczono klauzulą ,poufne” czy wyższą, może nastąpić po uzyskaniu poświadczenia bezpieczeństwa oraz po odbyciu szkolenia w zakresie ochrony informacji niejawnych ${ }^{2}$. Obie przesłanki muszą być spełnione łącznie, musi zatem danej osobie zostać wydane poświadczenie bezpieczeństwa oraz musi ona przejść szkolenie obejmujące sferę ochrony informacji niejawnych. Wyjątek od tej zasady wprowadza art. 34 u.o.i.n. zawierający katalog podmiotów zwolnionych, w stosunku do których nie przeprowadza się postępowania sprawdzającego. To, czy dana osoba może mieć wgląd do informacji niejawnych, jest oceniane przez pryzmat rękojmi zachowania tajemnicy. Ocena, czy ta osoba daje ową rękojmię, czy też nie, jest wystawiana co do zasady po przeprowadzeniu postępowania sprawdzającego.

Inne wymogi wprowadza ustawodawca w przypadku dostępu do informacji ,zastrzeżonych”. Jak wskazuje art. 21 ust. 4 u.o.i.n., dopuszczenie do pracy bądź pełnienia służby na stanowiskach albo zlecenie prac, co ma być związane $\mathrm{z}$ dostępem danej osoby do informacji niejawnych o klauzuli „zastrzeżone”, może nastąpić po: 1) pisemnym upoważnieniu przez kierownika jednostki organizacyjnej, jeżeli nie ma ona poświadczenia bezpieczeństwa; 2) odbyciu szkolenia w zakresie ochrony informacji niejawnych. Szkolenie jest obowiązkowe w przypadku informacji niejawnych bez względu na klauzulę tajności ${ }^{3}$. Poświadczenie

${ }^{1}$ S. Zalewski, Postępowanie sprawdzajace - instrument bezpieczeństwa państwa ujęty w ramach administracyjnych, [w:] Ochrona informacji niejawnych i biznesowych, red. M. Ciecierski, M. Gajos, Katowice 2007, s. 185.

2 Art. 21 ust. 1 Ustawy z dnia 5 sierpnia 2010 r. o ochronie informacji niejawnych (t.j. Dz.U. z 2016 r. poz. 1167 ze zm.), dalej: u.o.i.n.

${ }^{3}$ Ustawodawca pominął obowiązek przeprowadzenia postępowań sprawdzających wobec osób, które mają uzyskać dostęp do informacji niejawnych o klauzuli „zastrzeżone”. W związku 
bezpieczeństwa nie jest wymagane w przypadku dostępu do informacji „zastrzeżonych" - wymagane jest tylko upoważnienie wydane przez kierownika jednostki organizacyjnej (podmiotu wymienionego w art. 1 ust. 2 u.o.i.n.), lecz musi mieć ono dla swej ważności formę pisemną.

\section{Postępowanie sprawdzające prowadzone w celu ustalenia, czy osoba nim objęta daje rękojmię zachowania tajemnicy (postępowanie sprawdzające)}

W zależności od stanowiska bądź też wykonywania czynności zleconych, o które ubiega się osoba sprawdzana, przeprowadza się zwykłe lub poszerzone postępowanie sprawdzające, o czym stanowi art. 22 u.o.i.n. ${ }^{4}$ Według tego przepisu zwykłe postępowanie sprawdzające przeprowadzane jest w przypadku stanowisk i prac, które są związane z dostępem do informacji niejawnych o klauzuli „poufne", chyba że dotyczy to osób, co do których ustawodawca wymaga przeprowadzenia poszerzonego postępowania sprawdzającego. Jednak pomimo że będzie przeprowadzone w stosunku do tych osób postępowanie sprawdzające o charakterze kwalifikowanym (poszerzone), to i tak wydane poświadczenia bezpieczeństwa, upoważniające do dostępu do informacji niejawnych, będą pozwalały na dostęp do informacji o takiej klauzuli tajności, jaka została wskazana we wniosku lub poleceniu, chociażby miał to być dostęp tylko do informacji poufnych. Poszerzone postępowanie sprawdzające przeprowadza się: 1) przy stanowiskach oraz pracach związanych z dostępem do informacji niejawnych opatrzonych klauzulą „tajne” lub „ściśle tajne”; 2) w stosunku do pełnomocników ochrony, zastępców pełnomocników ochrony, jak też kandydatów na powyższe stanowiska; 3) w stosunku do kierowników jednostek organizacyjnych, w których są przetwarzane informacje niejawne co najmniej o klauzuli „poufne”; 4) w stosunku do osób ubiegających się o dostęp do informacji niejawnych międzynarodowych bądź też o dostęp, który ma wynikać z umowy międzynarodowej zawartej przez RP. Podziałowi informacji niejawnych odbywającemu się poprzez przyznanie właściwej

z tym wprowadzono system obowiązujący w większości krajów Europy, zakładający, że poświadczenia bezpieczeństwa są potrzebne od poziomu „poufne” wzwyż, a podstawą udostępnienia informacji niejawnych o najniższej klauzuli jest potrzeba, która wynika z wykonywania określonych obowiązków służbowych. K. Chałubińska-Jentkiewicz, Ochrona informacji niejawnych, [w:] Prawo bezpieczeństwa informacyjnego, red. M. Karpiuk, K. Chałubińska-Jentkiewicz, Warszawa 2015, s. 159.

${ }^{4}$ Postępowania sprawdzające, przeprowadzane na podstawie u.o.i.n., cechują się wysokim stopniem sformalizowania. A. Jędruszczak, R. Marek, Postępowanie sprawdzające oraz kontrolne postepowanie sprawdzajace, [w:] Ochrona danych osobowych $i$ informacji niejawnych $w$ sektorze publicznym, red. A. Gałach et al., Warszawa 2015, s. 254. 
klauzuli tajności towarzyszy podział postępowań sprawdzających. Podyktowane jest to względami z jednej strony bezpieczeństwa, z drugiej zaś - ekonomiki ${ }^{5}$.

Zwykłe postępowanie sprawdzające jest postępowaniem wnioskowym, przeprowadza je pełnomocnik do spraw ochrony informacji niejawnych, a pisemne polecenie $\mathrm{w}$ tej sprawie przekazuje mu kierownik jednostki organizacyjnej. Poszerzone postępowanie sprawdzające jest również postępowaniem przeprowadzanym na wniosek, a właściwa w tym zakresie jest Agencja Bezpieczeństwa Wewnętrznego oraz Służba Kontrwywiadu Wojskowego. Postępowanie sprawdzające (zwykłe i poszerzone) samodzielnie przeprowadzają również Agencja Wywiadu, Centralne Biuro Antykorupcyjne, Biuro Ochrony Rządu, Policja, Służba Więzienna, Służba Wywiadu Wojskowego, Straż Graniczna czy też Żandarmeria Wojskowa w stosunku do ściśle określonego w art. 23 ust. 5 u.o.i.n. kręgu adresatów ${ }^{6}$.

Agencja Bezpieczeństwa Wewnętrznego oraz Służba Kontrwywiadu Wojskowego prowadzą poszerzone postępowania sprawdzające $\mathrm{w}$ ramach sprawowania funkcji nadzoru nad funkcjonowaniem systemu ochrony informacji niejawnych ${ }^{7}$.

Cel postępowania sprawdzającego został określony w art. 24 ust. 1 u.o.i.n., a jest nim ustalenie, czy osoba sprawdzana daje rękojmię zachowania tajemnicy. Rękojmia zachowania tajemnicy została zdefiniowana przez ustawodawcę $\mathrm{w}$ art. 2 pkt 2 u.o.i.n. - jest nią zdolność osoby do spełnienia ustawowych wymogów w celu zagwarantowania ochrony informacji niejawnych przed ich nieuprawnionym ujawnieniem. Rękojmia zachowania tajemnicy jest stwierdzana w wyniku przeprowadzonego postępowania sprawdzającego. W przypadku jego braku zatem trudno mówić o dawaniu, bądź nie, takiej rękojmi. Ustawodawca przyjął, że w przypadku nieprzeprowadzenia postępowania sprawdzającego (bez znaczenia, czy jest to postępowanie zwykłe, czy poszerzone) przymiotu dawania rękojmi zachowania tajemnicy nie można danej osobie przypisać, podobnie jak w przypadku, gdy po przeprowadzeniu postępowania sprawdzającego organ co do takiej rękojmi wypowiedział się negatywnie.

W przypadku dostępu danej osoby do informacji niejawnych o klauzuli „zastrzeżone” nie przeprowadza się postępowania sprawdzającego, w związku z czym instytucja prawna, jaką jest ,rękojmia zachowania tajemnicy”, jako przesłanka ochrony informacji niejawnych o klauzuli co najmniej „poufne” została w tym przypadku pominięta przez ustawodawcę. Rękojmia ta jest stwierdzana

5 S. Hoc, T. Szewc, Ochrona danych osobowych i informacji niejawnych, Warszawa 2014, s. 151.

${ }^{6}$ Zob. także: M. Karpiuk, Zakres dziatania stużb specjalnych, [w:] Stużby specjalne w strukturze władz publicznych. Zagadnienia prawnoustrojowe, red. M. Bożek et al., Warszawa 2014, s. 68-69; K. Walczuk, M. Bożek, Konstytucyjne i ustawowe uwarunkowania organizacji i funkcjonowania Agencji Bezpieczeństwa Wewnętrznego, Siedlce 2015, s. 100-101; M. Karpiuk, Stużba Kontrwywiadu Wojskowego jako podmiot prawa obronnego, [w:] Prawo obronne Rzeczypospolitej Polskiej w zarysie, red. M. Czuryk, W. Kitler, Warszawa 2014, s. 186.

7 M. Czuryk, Informacja w administracji publicznej, Warszawa 2015, s. 174. 
w wyniku przeprowadzenia postępowania sprawdzającego, którego brak przy informacjach zastrzeżonych.

Ustawodawca wyraźnie wskazuje, co należy ustalić w ramach postępowania sprawdzającego. W toku tegoż postępowania ustaleniu podlega to, czy istnieją uzasadnione wątpliwości dotyczące: 1) uczestnictwa, współpracy czy też popierania przez osobę sprawdzaną działalności szpiegowskiej, terrorystycznej, sabotażowej albo innej wymierzonej przeciwko Rzeczypospolitej Polskiej — art. 24 ust. 2 pkt 1 u.o.i.n. Do zaistnienia tego warunku nie jest konieczna czynna aktywność obejmująca działania wymierzone przeciwko RP, wystarczy tylko poparcie takiej działalności. Podmiot prowadzący postępowanie sprawdzające musi mieć jednak racjonalne podstawy do stwierdzenia, że zachodzi przesłanka popierania (jak też uczestnictwa czy współpracy) odnośnie do działalności wymierzonej w szeroko rozumiane interesy RP. Wątpliwości tego rodzaju muszą być uzasadnione; 2) zagrożenia osoby sprawdzanej ze strony obcych służb specjalnych w postaci prób werbunku lub nawiązania z nią kontaktu - art. 24 ust. 2 pkt 2 u.o.i.n. Osoba sprawdzana nie musi działać (czy popierać działań) przeciwko RP, wręcz przeciwnie - w swojej aktywności może kierować się „racją stanu” i nie uzyska dostępu do informacji niejawnych. Wystarczy, że obce służby będą próbowały taką osobę zwerbować czy się z nią skontaktować; 3) przestrzegania porządku konstytucyjnego RP, w tym przede wszystkim ustalenie, czy osoba sprawdzana uczestniczyła lub uczestniczy w działalności partii politycznych lub innych organizacji zakazanych (które w swoich programach odwołują się do totalitarnych metod oraz praktyk działania nazizmu, faszyzmu i komunizmu, czy też których program lub działalność zakłada lub dopuszcza nienawiść rasową oraz narodowościową, stosowanie przemocy w celu zdobycia władzy bądź wpływu na politykę państwa lub przewiduje utajnienie struktur lub członkostwa ${ }^{8}$ ) albo współpracowała lub współpracuje z takimi partiami lub organizacjami — art. 24 ust. 2 pkt 3 u.o.i.n. W ramach przesłanki przestrzegania porząaku konstytucyjnego obowiązującego w państwie ustawodawca zwraca uwagę na przynależność oraz współpracę z organizacjami, których nie tylko działalność, ale i istnienie jest zakazane; 4) ukrywania bądź też świadomego niezgodnego z prawdą podawania $\mathrm{w}$ ankiecie bezpieczeństwa osobowego (lub postępowaniu sprawdzającym) przez osobę sprawdzaną informacji, które mają znaczenie dla ochrony informacji niejawnych - art. 24 ust. 2 pkt 4 u.o.i.n. Działania osoby sprawdzanej analizowane na gruncie tego przepisu muszą być podejmowane świadomie, a ich celem jest ostatecznie uzyskanie dostępu do informacji niejawnych; 5) wystąpienia

${ }^{8} \mathrm{Z}$ polskiego życia publicznego wyklucza się wszelkie organizacje, które w swojej działalności (chociażby tylko w programach) odwołują się do doktryn i praktyk totalitaryzmu. P. Winczorek, Komentarz do Konstytucji Rzeczypospolitej Polskiej z dnia 2 kwietnia 1997 roku, Warszawa 2008, s. 43. Władze publiczne zobowiązane są do przeciwdziałania wszelkim próbom tworzenia organizacji o charakterze totalitarnym bądź przynajmniej do monitorowania takich prób. B. Banaszak, Konstytucja Rzeczypospolitej Polskiej. Komentarz, Warszawa 2009, s. 102. 
związanych z osobą sprawdzaną okoliczności, które powodują ryzyko jej podatności na szantaż lub wywieranie presji — art. 24 ust. 2 pkt 5 u.o.i.n.; 6) niewłaściwego postępowania $\mathrm{z}$ informacjami niejawnymi. Tutaj art. 24 ust. 2 pkt 6 u.o.i.n. wskazuje, że ma to miejsce, gdy: doprowadziło to bezpośrednio do ujawnienia takich informacji osobom nieuprawnionym, było to wynikiem celowego działania, stwarzało realne zagrożenie wynikające $\mathrm{z}$ nieuprawnionego ujawnienia tych informacji oraz nie miało charakteru incydentalnego, a dopuściła się tego osoba szczególnie zobowiązana na podstawie u.o.i.n. do ochrony informacji niejawnych — pełnomocnik ochrony, jego zastępca lub kierownik kancelarii tajnej.

W trakcie poszerzonego postępowania sprawdzającego, jak wskazuje art. 24 ust. 3 u.o.i.n., ustala się dodatkowo, czy istnieją wątpliwości dotyczące: 1) poziomu życia osoby sprawdzanej, który wyraźnie przewyższa uzyskiwane przez nią dochody; 2) informacji o chorobie psychicznej bądź też innych zakłóceniach czynności psychicznych, które ograniczają sprawność umysłową oraz mogą negatywnie wpłynąć na zdolność osoby sprawdzanej co do wykonywania prac związanych z dostępem do informacji niejawnych; 3) uzależnienia od alkoholu, środków odurzających lub substancji psychotropowych ${ }^{9}$. Możliwość wejścia w posiadanie tak szczegółowych informacji o osobie sprawdzanej wynika z przyznania przez ustawodawcę prymatu ochrony informacji niejawnych przed innymi prawnie chronionymi interesami, co staje się wystarczające m.in. do ograniczenia prawa do prywatności ${ }^{10}$.

W kontekście art. 24 ust. 3 u.o.i.n. mówi się o wątpliwościach odnoszących się do sytuacji opisanych $\mathrm{w}$ tym przepisie, gdy na gruncie art. 24 ust. 2 u.o.i.n. ustawodawca zastrzegł, że w stosunku do przesłanek tam wskazanych muszą zaistnieć „uzasadnione” wątpliwości. Ten drugi przepis zatem nakłada dodatkowe obowiązki na organ prowadzący postępowanie sprawdzające, gdyż musi on wykazać istnienie wątpliwości „,uzasadnionych”, a nie „zwykłych”.

W przypadku napotkania niedających się usunąć wątpliwości interes ochrony informacji niejawnych ma pierwszeństwo przed innymi prawnie chronionymi interesami, którą to zasadę wprost formułuje art. 24 ust. 4 u.o.i.n. Niedające się usunąc wątpliwości w tym przypadku zatem nie będą przemawiały na korzyść osoby sprawdzanej, a wręcz przeciwnie — będą działały na jej niekorzyść, gdyż pierwszeństwo w tym przypadku przyznaje się ochronie informacji niejawnych jako wartości nadrzędnej.

Kolejne zasady obowiązujące w toku postępowania sprawdzającego są dekodowane na gruncie art. 24 ust. 5 u.o.i.n., a należą do nich zasady: bezstronności,

9 Organ uprawniony do przeprowadzenia poszerzonego postępowania sprawdzającego, w zakresie koniecznym do wykonywania swoich zadań, może zwracać się do „innych podmiotów” o udzielenie niezbędnej pomocy przy wykonywaniu czynności w ramach prowadzonego postępowania sprawdzającego. M. Karpiuk, Informacje niejawne i ich rola w sferze wykonywania administracji publicznej, [w:] Informacja i informatyzacja w administracji publicznej, red. M. Karpiuk, K. Chałubińska-Jentkiewicz, Warszawa 2015, s. 40.

10 M. Wujczyk, Prawo pracownika do ochrony prywatności, Warszawa 2012, s. 235. 
obiektywizmu oraz najwyższej staranności w zakresie przestrzegania u.o.i.n. Zasadę dokumentowania wprowadza z kolei art. 24 ust. 6 u.o.i.n.; w związku z nią wszystkie czynności, które są przeprowadzane w toku postępowania sprawdzającego, muszą być rzetelnie udokumentowane oraz powinny być zakończone przed upływem 3 miesięcy liczonych od dnia złożenia do pełnomocnika ochrony wypełnionej ankiety lub złożenia wniosku o przeprowadzenie postępowania sprawdzającego wraz z wypełnioną ankietą. Jednak ów trzymiesięczny termin jest terminem instrukcyjnym. W przypadku jego niedotrzymania, co wynika $\mathrm{z}$ art. 24 ust. 7 u.o.i.n., organ prowadzący postępowanie sprawdzające informuje, na wniosek osoby sprawdzanej, o przewidywanym terminie zakończenia postępowania oraz (o ile to nie naruszy zasad ochrony informacji niejawnych) o powodach przedłużania się postępowania. Ustawodawca nie wskazuje, o ile może być to postępowanie przedłużone ponad termin podstawowy — trzymiesięczny. Organ przy tym nie działa z urzędu, stosowna informacja jest przygotowywana na wniosek osoby sprawdzanej; organ nie zawsze jest także zobowiązany do uzasadnienia przedłużenia terminu procedowania.

W świetle art. 25 u.o.i.n. zwykłe postępowanie sprawdzające obejmuje następujące czynności: 1) sprawdzenie, w niezbędnym zakresie, w ewidencjach, rejestrach i kartotekach, w szczególności w Krajowym Rejestrze Karnym, danych zawartych w wypełnionej oraz podpisanej przez osobę sprawdzaną ankiecie, jak również sprawdzenie innych informacji uzyskanych w toku postępowania sprawdzającego w zakresie, który jest niezbędny do ustalenia, czy osoba sprawdzana daje rękojmię zachowania tajemnicy; 2) sprawdzenie w ewidencjach i kartotekach niedostępnych powszechnie danych zawartych w ankiecie, a także innych informacji uzyskanych $\mathrm{w}$ toku postępowania sprawdzającego w zakresie, który jest niezbędny do ustalenia, czy osoba sprawdzana daje rękojmię zachowania tajemnicy. Zwykłe postępowanie sprawdzające obejmuje ponadto rozmowę z osobą sprawdzaną, jeżeli uzyskane w jego toku informacje wskazują, że jest to niezbędne. W przypadku gdy w ramach zwykłego postępowania sprawdzającego wystąpią wątpliwości, które nie pozwalają na ustalenie, czy osoba sprawdzana daje rękojmię zachowania tajemnicy, organ prowadzący to postępowanie zapewnia osobie sprawdzanej w trakcie wysłuchania możliwość osobistego odniesienia się do informacji, które powodują powstanie tych wątpliwości. Osoba ta może stawić się na wysłuchanie wraz ze swoim pełnomocnikiem. Z przebiegu wysłuchania sporządza się protokół — podpisuje go osoba prowadząca wysłuchanie, osoba wysłuchana, jak również pełnomocnik, jeżeli w nim uczestniczył. Odstępuje się od osobistego odniesienia się do informacji, które powodują powstanie wątpliwości co do rękojmi zachowania tajemnicy podczas wysłuchania, gdy: 1) przeprowadzenie tych czynności wiązałoby się z ujawnieniem informacji niejawnych; 2) postępowanie sprawdzające doprowadziło do niebudzącego wątpliwości ustalenia, że osoba sprawdzana nie daje rękojmi zachowania tajemnicy. Zwykłe postępowanie sprawdzające obejmuje potwierdzenie danych wpisanych 
do ankiety bezpieczeństwa osobowego. W związku z tym pierwszą czynnością powinna być analiza tej ankiety. Jej celem jest ocena, czy dane zawarte w ankiecie wymagają potwierdzenia, wyjaśnienia bądź uzupełnienia ${ }^{11}$.

$\mathrm{W}$ ramach postępowania sprawdzającego analizie podlegają te informacje, które mają związek ze stwierdzeniem, czy osoba sprawdzana daje rękojmię zachowania tajemnicy. Bazę informacyjną dla organu prowadzącego postępowanie sprawdzające stanowią kartoteki, rejestry czy ewidencje zarówno powszechnie dostępne, jak i te, do których dostęp jest ograniczony. Może być również przeprowadzona rozmowa z osobą sprawdzaną, co do uzupełnienia bądź wyjaśnienia informacji będących w posiadaniu organu prowadzącego postępowanie, gdy ten ma wątpliwości co do tego, że po stronie osoby sprawdzanej występuje zdolność do spełnienia ustawowych wymogów do zapewnienia ochrony informacji niejawnych przed ich nieuprawnionym ujawnieniem.

Czynności właściwe poszerzonemu postępowaniu sprawdzającemu określa art. 26 u.o.i.n., a należą do nich czynności zwykłego postępowania sprawdzającego wynikające $\mathrm{z}$ art. 25 ust. 1 u.o.i.n. oraz (jeśli jest to konieczne): 1) rozmowa z przełożonymi osoby sprawdzanej oraz z innymi osobami; 2) wywiad w miejscu zamieszkania osoby sprawdzanej; 3) sprawdzenie stanu i obrotów na rachunku bankowym oraz zadłużenia osoby sprawdzanej, w szczególności wobec Skarbu Państwa. Celem zbadania, czy osoba sprawdzana daje rękojmię zachowania tajemnicy, w przypadku poszerzonego postępowania sprawdzającego organ prowadzący postępowanie powinien, gdy okoliczności tego wymagają, przeprowadzić rozmowę przede wszystkim z przełożonymi osoby sprawdzanej, ale nie tylko - krąg tych osób nie jest zamknięty. Rozmowa powinna być przeprowadzona z tymi osobami, które mogą rozwiać wątpliwości organu co do wiarygodności przedstawionych informacji oraz rękojmi zachowania tajemnicy.

Wynik wywiadu w miejscu zamieszkania osoby sprawdzanej, przeprowadzany w ramach poszerzonego postępowania sprawdzającego, powinien zawierać m.in.: 1) imię i nazwisko osoby przeprowadzającej wywiad; 2) imię i nazwisko osoby sprawdzanej; 3) zwięzły opis dotychczasowego życia osoby sprawdzanej oraz dokładne informacje o jej środowisku, w tym rodzinnym, szkolnym lub zawodowym, a ponadto informacje o jej stanie majątkowym i źródłach dochodów; 4) informacje dotyczące stanu zdrowia osoby sprawdzanej, a także nadużywania przez nią alkoholu, środków odurzających, środków zastępczych lub substancji psychotropowych; 5) własne spostrzeżenia i konkluzje osoby przeprowadzającej wywiad, zwłaszcza dotyczące właściwości i warunków osobistych oraz dotychczasowego sposobu życia osoby sprawdzanej ${ }^{12}$. Konkluzje, które powinny się

11 I. Stankowska, Ustawa o ochronie informacji niejawnych. Komentarz, Warszawa 2014, s. 101

12 Art. 26 ust. 2 u.o.i.n. w zw. z art. 214 § 4 Ustawy z dnia 6 czerwca 1997 r. Kodeks postępowania karnego (Dz.U. Nr 89, poz. 555 ze zm.), dalej: k.p.k. Patrz także: K.T. Boratyńska, [w:] Kodeks postępowania karnego. Komentarz, red. K.T. Boratyńska et. al., Warszawa 2014, s. 427. 
znaleźć w wywiadzie, to wnioski, jakie się nasuwają osobie przeprowadzającej wywiad na podstawie zebranych informacji oraz własnych spostrzeżeń. W związku z tym powinny one wynikać $\mathrm{z}$ całokształtu materiału dowodowego ${ }^{13}$.

Ustawodawca w art. $214 \S 4$ k.p.k. nie wymienia wszystkich elementów wywiadu środowiskowego. W jego ramach należy zatem zgromadzić wszelkie istotne w sprawie informacje, również te, które pominął ustawodawca ${ }^{14}$.

Wywiad przeprowadza się w miejscu zamieszkania i pobytu osoby sprawdzanej oraz w miejscu jej pracy lub nauki. Osoba przeprowadzająca wywiad zbiera niezbędne informacje od rodziny osoby sprawdzanej i sąsiadów, jej przełożonych w miejscu pracy oraz od innych osób lub instytucji, które mogą dysponować niezbędną wiedzą o osobie sprawdzanej ${ }^{15}$.

W przypadku przesłanki ,sprawdzenia stanu i obrotów na rachunku bankowym" występującej w ramach poszerzonego postępowania sprawdzającego bank ma obowiązek udzielenia informacji stanowiących tajemnicę bankową Agencji Bezpieczeństwa Wewnętrznego, Służbie Kontrwywiadu Wojskowego, Agencji Wywiadu, Służbie Wywiadu Wojskowego, Centralnemu Biuru Antykorupcyjnemu, Policji, Żandarmerii Wojskowej, Straży Granicznej, Służbie Więziennej, Biuru Ochrony Rządu i posiadających ich pisemne upoważnienie funkcjonariuszom lub żołnierzom, jednak tylko $\mathrm{w}$ zakresie niezbędnym do przeprowadzenia postępowania sprawdzającego ${ }^{16}$. Bank jest również zobowiązany do sporządzania

13 T. Grzegorczyk, Kodeks postępowania karnego. Komentarz, t. I, Warszawa 2014, s. 773.

14 L.K. Paprzycki, [w:] Kodeks postępowania karnego. Komentarz, red. L.K. Paprzycki, Warszawa 2013, s. 718.

15 Art. 26 ust. 2 u.o.i.n. w zw. z $§ 2$ Rozporządzenia Ministra Sprawiedliwości z dnia 11 czerwca 2003 r. w sprawie regulaminu czynności w zakresie przeprowadzania wywiadu środowiskowego oraz wzoru kwestionariusza tego wywiadu (Dz.U. Nr 108, poz. 1018). W myśl § 5 tego rozporządzenia wywiad obejmuje informacje dotyczące: 1) zachowania osoby poddanej wywiadowi; 2) warunków środowiskowych osoby poddanej wywiadowi; 3) sytuacji bytowej osoby poddanej wywiadowi i jego rodziny; 4) sposobu spędzania przez osobę poddaną wywiadowi wolnego czasu; 5) przebiegu i oceny pracy zawodowej lub nauki osoby poddanej wywiadowi; 6) kontaktów osoby poddanej wywiadowi ze środowiskowymi grupami patologii społecznej, z uwzględnieniem nadużywających alkoholu lub środków odurzających; 7) stanu zdrowia osoby poddanej wywiadowi, z uwzględnieniem stanu zdrowia psychicznego, uzależnienia od alkoholu lub środków odurzających.

16 Art. 26 ust. 3 u.o.i.n. w zw. z art. 105 ust. 1 pkt 2 lit. k Ustawy z dnia 29 sierpnia 1997 r. Prawo bankowe (t.j. Dz.U. z 2015 r. poz. 128 ze zm.), dalej: p.b. Art. 105 ust. 1 p.b. nakłada na bank obowiązek udzielenia informacji stanowiących tajemnicę bankową konkretnym, wymienionym w tym przepisie podmiotom, we wskazanych tam sytuacjach. B. Smykla, Prawo bankowe. Komentarz, Warszawa 2011, s. 430. Na banku ciąży zatem ustawowy obowiązek udzielania informacji konfidencjonalnych upoważnionym podmiotom. M. Bączyk, [w:] Prawo bankowe. Komentarz, red. E. Fojcik-Mastalska, Warszawa 2005, s. 515. Zgodnie z zasadą maksymalizmu zakresem przedmiotowym tajemnicy bankowej objęte są wszystkie informacje, poza wyjątkami przedmiotowymi określonymi w art. 104 ust. 2 p.b. oraz wyjątkami dotyczącymi udzielania danych informacji ściśle określonym podmiotom, uprawnionym do tego z mocy ustawy, co z kolei wynika z art. 105 ust. 1-2 p.b. - Wyrok WSA z dnia 20 maja 2008 r., I SA/Kr 115/08, LEX Nr 475534. Żądanie udostępnienia informacji objętych tajemnicą bankową na gruncie art. 105 ust. 1 pkt 2 lit. k p.b. w każdym przypad- 
i przekazywania informacji dotyczących osoby sprawdzanej w zakresie: 1) posiadanych rachunków bankowych lub posiadanych pełnomocnictw do dysponowania rachunkami bankowymi, liczby tych rachunków lub pełnomocnictw, obrotów i stanów tych rachunków, z podaniem wpływów, obciążeń rachunków i ich tytułów oraz odpowiednio ich nadawców i odbiorców; 2) posiadanych rachunków pieniężnych, rachunków papierów wartościowych lub posiadanych pełnomocnictw do dysponowania takimi rachunkami, liczby tych rachunków, a także obrotów i stanów tych rachunków; 3) zawartych umów kredytowych lub umów pożyczki, z podaniem wysokości zobowiązań wynikających z tych kredytów lub pożyczek, celów, na jakie zostały udzielone, i sposobu zabezpieczenia ich spłaty, a także umów depozytowych i umów udostępniania skrytek sejfowych; 4) nabytych za pośrednictwem banków akcji Skarbu Państwa lub obligacji Skarbu Państwa, a także obrotu tymi papierami wartościowymi; 5) obrotu wydawanymi przez banki certyfikatami depozytowymi lub innymi papierami wartościowymi ${ }^{17}$. Bank jest zobowiązany na pisemne żądanie organu prowadzącego poszerzone postępowanie sprawdzające do sporządzenia i przekazania informacji dotyczących osoby sprawdzanej w zakresie: 1) posiadanych rachunków bankowych lub rachunków oszczędnościowych, liczby tych rachunków, a także obrotów i stanów tych rachunków; 2) posiadanych rachunków pieniężnych lub rachunków papierów wartościowych, liczby tych rachunków, a także obrotów i stanów tych rachunków; 3) zawartych umów kredytowych lub umów pożyczek pieniężnych, a także umów depozytowych; 4) nabytych za pośrednictwem banków akcji Skarbu Państwa lub obligacji Skarbu Państwa, a także obrotu tymi papierami wartościowymi; 5) obrotu wydawanymi przez banki certyfikatami depozytowymi lub innymi papierami wartościowymi. To ma również zastosowanie do zakładów ubezpieczeń, funduszy inwestycyjnych, dobrowolnych funduszy emerytalnych i banków prowadzących działalność maklerską, w zakresie prowadzonych indywidualnych kont emerytalnych oraz indywidualnych kont zabezpieczenia emerytalnego, a także do domów maklerskich oraz spółdzielczych kas oszczędnościowo-kredytowych ${ }^{18}$. Obowiąz-

ku musi się mieścić w granicach prowadzonego postępowania sprawdzającego. Z. Ofiarski, Prawo bankowe. Komentarz, Warszawa 2013, s. 675. Wprowadzenie ograniczenia prywatności w zakresie przewidzianym w art. 105 ust. 1 pkt 2 lit. k p.b. wynika z potrzeby zapewnienia przez prawodawcę bezpieczeństwa państwa, jak też porządku publicznego. A. Żegadło, Wyłączenie tajemnicy bankowej a prawo do prywatności, Warszawa 2011, s. 271.

17 Art. 26 ust. 3 u.o.i.n. w zw. z art. 33 ust. 1 Ustawy z dnia 28 września 1991 r. o kontroli skarbowej (t.j. Dz.U. z 2015 r., poz. 553 ze zm.), dalej u.k.s. Patrz także: J. Kulicki, Kontrola skarbowa. Komentarz, Warszawa 2013, s. 628-629. Banki nie mają prawa udzielania innych informacji niż określone w art. 33 u.k.s. W przypadku złożenia żądania wykraczającego poza ten obszar bank odmawia udzielenia informacji w tym zakresie, G. Pelewicz, [w:] Ustawa o kontroli skarbowej. Komentarz, red. K. Kandut, A. Sędkowska, Warszawa 2014, s. 482.

18 Art. 26 ust. 3 u.o.i.n. w zw. z art. 182 Ustawy z dnia 29 sierpnia 1997 r. Ordynacja podatkowa (t.j. Dz.U. z 2015 r. poz. 613 ze zm.), dalej: o.p. Art. 182 o.p. określa nadzwyczajny środek dowodowy polegający na możliwości żądania uchylenia tajemnicy bankowej. B. Dauter, [w:] Ordynacja podatkowa. Komentarz, red. S. Babiarz et al., Warszawa 2011, s. 765. 
ki nałożone przez ustawodawcę na bank i inne wskazane podmioty odnoszą się także do badania „stanu zadłużenia osoby sprawdzanej”.

Ustawodawca w art. 26 ust. 3 u.o.i.n. w zw. z art. $82 \S 1$ o.p. nakłada obowiązek sporządzania i przekazywania informacji o zdarzeniach wynikających ze stosunków cywilnoprawnych albo z prawa pracy, mogących mieć wpływ na powstanie obowiązku podatkowego lub wysokość zobowiązania podatkowego osób lub jednostek, z którymi zawarto umowę, a także o umowach zawartych z nierezydentami ${ }^{19}$, co ma związek z przesłanką ,stanu zadłużenia osoby sprawdzanej wobec Skarbu Państwa”.

Bieg postępowania sprawdzającego przerywa instytucja zawieszenia. Przesłanki zawieszenia wprowadza art. 27 ust. 1 u.o.i.n., a należą do nich: 1) trwająca powyżej 30 dni choroba osoby sprawdzanej, która uniemożliwia skuteczne przeprowadzenie postępowania sprawdzającego; 2) wyjazd za granicę osoby sprawdzanej na okres przekraczający 30 dni; 3) konieczność uprzedniego rozstrzygnięcia zagadnienia przez inny organ, w szczególności w przypadku wszczęcia przeciwko osobie sprawdzanej postępowania karnego w sprawie o przestępstwo umyślne ścigane z oskarżenia publicznego bądź też umyślne przestępstwo skarbowe; 4) inne przyczyny niezależne od organu prowadzącego postępowanie sprawdzające. Wyjazd za granicę lub choroba trwające ponad 30 dni uniemożliwiają organowi właściwe przeprowadzenie postępowania sprawdzającego, gdy np. konieczne jest przeprowadzenie rozmowy z osobą sprawdzaną celem wyjaśnienia kwestii budzących wątpliwości co do rękojmi zachowania tajemnicy czy też występuje potrzeba przeprowadzenia wysłuchania. W przypadku wyjazdu za granicę mogą nastąpić nowe okoliczności, które organ prowadzący postępowanie sprawdzające powinien zbadać, m.in. co do kontaktów tam nawiązanych. Z kolei prejudykat uwzględniany $\mathrm{w}$ ramach postępowania sprawdzającego dotyczy przede wszystkim postępowania karnego czy też karno-skarbowego, lecz również powinien być brany pod uwagę w przypadku postępowania dyscyplinarnego czy też innego wpływającego na okoliczność dawania rękojmi zachowania tajemnicy.

Przypadki, gdy zawieszone postępowanie sprawdzające zostaje podjęte, określa art. 27 ust. 2 u.o.i.n. Następuje to, gdy: 1) ustąpiły przyczyny uzasadniające

19 Art. 82 § 1 pkt. 1 o.p. ustanawia jedynie ogólne, ,wstępne” uprawnienie organu do otrzymania informacji mogącej mieć wpływ na powstanie lub wysokość zobowiązania podatkowego - Wyrok WSA z dnia 10 grudnia 2007 r., II SA/Wa 1251/07, LEX Nr 445287. Nierezydentami, o których mowa w art. $82 \S 1$ pkt. 2 o.p., są: 1) osoby fizyczne mające miejsce zamieszkania za granicą oraz osoby prawne mające siedzibę za granicą, a także inne podmioty mające siedzibę za granicą, mające zdolność zaciągania zobowiązań i nabywania praw we własnym imieniu (nierezydentami są również znajdujące się za granicą oddziały, przedstawicielstwa i przedsiębiorstwa utworzone przez rezydentów); 2) obce przedstawicielstwa dyplomatyczne, urzędy konsularne i inne obce przedstawicielstwa oraz misje specjalne i organizacje międzynarodowe korzystające $\mathrm{z}$ immunitetów i przywilejów dyplomatycznych lub konsularnych - art. 2 ust. 1 pkt 2 Ustawy z dnia 27 lipca 2002 r. Prawo dewizowe (t.j. Dz.U. z 2012 r., poz. 826 ze zm.). Przyjęty podział podmiotów na rezydentów i nierezydentów oparty jest na jednolitym kryterium odwołującym się do miejsca zamieszkania lub siedziby. Z. Ofiarski, Prawo dewizowe. Komentarz, Kraków 2003, s. 35. 
zawieszenie postępowania; 2) ujawniono okoliczności, które mogą stanowić podstawę do odmowy wydania poświadczenia bezpieczeństwa lub umorzenia postępowania sprawdzającego. Ustawodawca używa zwrotu ,zostaje podjęte” — zatem jeżeli wystąpią okoliczności z art. 27 ust. 2 u.o.i.n., organ, który zawiesił postępowanie sprawdzające, jest zobowiązany je podjąć.

$\mathrm{W}$ art. 28 u.o.i.n. przewiduje się trzy formy zakończenia postępowania sprawdzającego: 1) wydanie poświadczenia bezpieczeństwa; 2) odmowa wydania poświadczenia bezpieczeństwa; 3) umorzenie postępowania. Dochodząc do wniosku, że osoba sprawdzana daje rękojmię zachowania tajemnicy, organ rozstrzyga merytorycznie o wydaniu poświadczenia bezpieczeństwa; brak przekonania w tym zakresie skutkuje odmową wydania poświadczenia bezpieczeństwa, co też jest rozstrzygnięciem merytorycznym. Organ, gdy kończy postępowanie sprawdzające poprzez jego umorzenie, nie rozstrzyga merytorycznie, bazując przy tym na przesłankach wynikających z art. 31 u.o.i.n.

\section{Poświadczenie bezpieczeństwa}

Poświadczenie bezpieczeństwa ma charakter czasowy — według art. 29 ust. 3 u.o.i.n. wydaje się je na okres: 1) 10 lat, gdy dotyczy ono dostępu do informacji niejawnych o klauzuli „poufne”; 2) 7 lat, gdy dotyczy ono dostępu do informacji niejawnych o klauzuli „tajne”; 3) 5 lat, gdy dotyczy ono dostępu do informacji niejawnych o klauzuli ,ściśle tajne" ${ }^{20}$. Status informacji chronionych za pośrednictwem odpowiedniej klauzuli tajności jest tak istotny, że poświadczenie bezpieczeństwa wydawane jest na ściśle określony czas. Przy wydawaniu kolejnego organ musi każdorazowo i od początku oceniać, czy osoba sprawdzana spełnia ustawowe przesłanki uzasadniające wydanie poświadczenia bezpieczeństwa, a zatem czy daje rękojmię zachowania tajemnicy.

Ustawodawca dopuszcza badanie okoliczności uzasadniających wydanie poświadczenia bezpieczeństwa w trakcie jego obowiązywania, gdy właściwy organ uzyska nowe informacje, które wskazują, że osoba, której wydano takie poświadczenie, nie daje rękojmi zachowania tajemnicy. W takim przypadku przeprowadza się kontrolne postępowanie sprawdzające. Przeprowadza je, według art. 33 ust. 2-3 u.o.i.n., organ właściwy do przeprowadzenia kolejnego postępowania sprawdzającego, z tym że w przypadkach uzasadnionych względami bezpieczeństwa państwa kontrolne postępowanie sprawdzające może zostać przeprowadzone przez ABW albo SKW.

Formy zakończenia kontrolnego postępowania sprawdzającego określone zostały w art. 33 ust. 11 u.o.i.n. W świetle tego przepisu postępowanie to kończy

$20 \mathrm{~W}$ przedmiocie poświadczenia bezpieczeństwa zob. szerzej: M. Karpiuk, Odmowa wydania poświadczenia bezpieczeństwa przez polskie slużby ochrony państwa, „Secretum” 2015, $\mathrm{nr} 3$, s. $138-141$. 
się: 1) decyzją o cofnięciu poświadczenia bezpieczeństwa ${ }^{21}$;2) poinformowaniem kierownika jednostki organizacyjnej lub osoby uprawnionej do obsady stanowiska, pełnomocnika ochrony w jednostce organizacyjnej oraz osoby sprawdzanej o braku zastrzeżeń w stosunku do osoby, którą objęto kontrolnym postępowaniem sprawdzającym, z jednoczesnym potwierdzeniem dalszej jej zdolności do zachowania tajemnicy $\mathrm{w}$ zakresie określonym w posiadanym przez nią poświadczeniu bezpieczeństwa; 3) decyzją o umorzeniu postępowania w przypadku, gdy postępowanie to nie zostało zakończone przed upływem 12 miesięcy od dnia jego wszczęcia. Najdalej posuniętą dolegliwością dla osoby posiadającej poświadczenie bezpieczeństwa jest rozstrzygnięcie o cofnięciu poświadczenia bezpieczeństwa, które przekreśla możliwość dostępu do informacji niejawnych.

Prawodawca wyraźnie określa, jak ma wyglądać poświadczenie bezpieczeństwa. Poświadczenie bezpieczeństwa, które upoważnia do dostępu do informacji niejawnych o klauzuli ,poufne” bądź też wyższej, wydawane przez ABW albo SKW, sporządza się na papierze offsetowym w kolorze zielonym, formatu A4, z tłem rastrowanym i z tekstem o treści „Agencja Bezpieczeństwa Wewnętrznego” czy „Służba Kontrwywiadu Wojskowego” w zależności od tego, kto przeprowadził postępowanie sprawdzające. W przypadku poświadczenia bezpieczeństwa upoważniającego do dostępu do informacji niejawnych o klauzuli „poufne” bądź też wyższej, wydawanego przez AW, CBA, Biuro Ochrony Rządu, Policję, Służbę Więzienną, SWW, Straż Graniczną oraz Żandarmerię Wojskową, sporządza się je na papierze offsetowym w kolorze beżowym, formatu $\mathrm{A} 4$, $\mathrm{z}$ tłem rastrowanym i z tekstem o treści stanowiącej pełną nazwę służby, która przeprowadziła postępowanie sprawdzające. $Z$ kolei poświadczenia bezpieczeństwa wydawane przez pełnomocników do spraw ochrony informacji niejawnych (z wyjątkiem poświadczeń bezpieczeństwa wydawanych przez pełnomocników do spraw ochrony informacji niejawnych w ABW, SKW, AW, CBA, BOR, Policji, SW, SWW, SG, ŻW) sporządza się na papierze w kolorze białym, formatu $\mathrm{A} 44^{22}$.

21 Decyzje o cofnięciu poświadczenia bezpieczeństwa wydawane przez: 1) Agencję Bezpieczeństwa Wewnętrznego, Służbę Kontrwywiadu Wojskowego — sporządza się na papierze w kolorze jasnoszarym, formatu A4; 2) Agencję Wywiadu, Centralne Biuro Antykorupcyjne, Biuro Ochrony Rządu, Policję, Służbę Więzienną, Służbę Wywiadu Wojskowego, Straż Graniczną oraz Żandarmerię Wojskową - sporządza się na papierze w kolorze jasnofioletowym, formatu A4; 3) pełnomocników do spraw ochrony informacji niejawnych — sporządza się na papierze w kolorze białym, formatu A4. § 2 Rozporządzenia Prezesa Rady Ministrów z dnia 28 grudnia 2010 r. w sprawie wzoru decyzji o cofnięciu poświadczenia bezpieczeństwa (Dz.U. Nr 258, poz. 1754).

$22 \S 2$ Rozporządzenia Prezesa Rady Ministrów z dnia 28 grudnia 2010 r. w sprawie wzorów poświadczeń bezpieczeństwa (t.j. Dz.U. z 2015 r. poz. 220). 


\section{Zakończenie}

Instrumentarium ochronne zabezpieczające przed nieuprawnionym ujawnieniem informacji niejawnych jest bezpośrednio związane ze sferą bezpieczeństwa osobowego. Ze względu na cel uruchomienia tegoż instrumentarium, który urzeczywistnia się w potrzebie przeciwdziałania powstaniu szkody dla RP czy też potrzebie zapobiegania działaniom niekorzystnym dla jej interesów, nadanie stosownych uprawnień w zakresie dostępu do informacji niejawnych osobom dającym rękojmię zachowania tajemnicy musi być ściśle reglamentowane.

Zasada wiedzy niezbędnej, warunkująca zgodnie $\mathrm{z}$ art. 4 ust. 1 u.o.i.n. udostępnienie informacji niejawnych, oznacza, że zapoznanie się przez określoną osobę z informacjami niejawnymi ma służyć wykonywaniu przez tę osobę pracy lub pełnieniu służby na zajmowanym stanowisku albo wykonywaniu prac zleconych (umów), które są związane z dostępem do informacji niejawnych. Nikt w związku z tym nie może domagać się udostępnienia informacji niejawnych, nawet w przypadku, gdy posiada poświadczenie bezpieczeństwa do odpowiedniej klauzuli, o ile informacja taka nie jest niezbędna do wykonywania pracy lub pełnienia służby na zajmowanym stanowisku albo wykonywania czynności zleconych ${ }^{23}$.

\section{Bibliografia}

Banaszak B., Konstytucja Rzeczypospolitej Polskiej. Komentarz, Warszawa 2009.

Chałubińska-Jentkiewicz K., Ochrona informacji niejawnych, [w:] Prawo bezpieczeństwa informacyjnego, red. M. Karpiuk, K. Chałubińska-Jentkiewicz, Warszawa 2015.

Czuryk M., Informacja w administracji publicznej, Warszawa 2015.

Grzegorczyk T., Kodeks postepowania karnego. Komentarz, t. I, Warszawa 2014.

Hoc S., Szewc T., Ochrona danych osobowych i informacji niejawnych, Warszawa 2014.

Jędruszczak A., Marek R., Postępowanie sprawdzające oraz kontrolne postępowanie sprawdzajace, [w:] Ochrona danych osobowych i informacji niejawnych w sektorze publicznym, red. A. Gałach, S. Hoc, A. Jędruszczak, K. Kędzierska, P. Kowalik, A. Kuszel, M. Kuźma, R. Marek, B. Nowakowski, Warszawa 2015.

Karpiuk M., Informacje niejawne i ich rola $w$ sferze wykonywania administracji publicznej, [w:] Informacja i informatyzacja $w$ administracji publicznej, red. M. Karpiuk, K. Chałubińska-Jentkiewicz, Warszawa 2015, s. 40.

Karpiuk M., Odmowa wydania poświadczenia bezpieczeństwa przez polskie stużby ochrony państwa, „Secretum” 2015, nr 3.

Karpiuk M., Przestrzeń e-administracji i demokracji cyfrowej, [w:] Prawo nowych technologii. Wybrane zagadnienia, red. K. Chałubińska-Jentkiewicz, M. Karpiuk, Warszawa 2015.

Karpiuk M., Stużba Kontrwywiadu Wojskowego jako podmiot prawa obronnego, [w:] Prawo obronne Rzeczypospolitej Polskiej w zarysie, red. M. Czuryk, W. Kitler, Warszawa 2014.

Karpiuk M., Zakres działania stużb specjalnych, [w:] Stużby specjalne w strukturze władz publicznych. Zagadnienia prawnoustrojowe, red. M. Bożek, M. Czuryk, M. Karpiuk, J. Kostrubiec, Warszawa 2014.

23 Wyrok WSA z dnia 12 lutego 2015 r., II SA/Wa 1749/14, LEX Nr 1730389.

Studia nad Autorytaryzmem i Totalitaryzmem 40, nr 1, 2018

(C) for this edition by CNS 
Kodeks postępowania karnego. Komentarz, red. K.T. Boratyńska, A. Górski, A. Sakowicz, A. Ważny, Warszawa 2014.

Kodeks postepowania karnego. Komentarz, red. L.K. Paprzycki, Warszawa 2013.

Kulicki J., Kontrola skarbowa. Komentarz, Warszawa 2013.

Ochrona danych osobowych i informacji niejawnych w sektorze publicznym, red. A. Gałach, S. Hoc, A. Jędruszczak, K. Kędzierska, P. Kowalik, A. Kuszel, M. Kuźma, R. Marek, B. Nowakowski, Warszawa 2015.

Ofiarski Z., Prawo bankowe. Komentarz, Warszawa 2013.

Ofiarski Z., Prawo dewizowe. Komentarz, Kraków 2003.

Ordynacja podatkowa. Komentarz, red. S. Babiarz, B. Dauter, B. Gruszczyński, R. Hauser, A. Kabat, M. Niezgódka-Medek, Warszawa 2011.

Prawo bankowe. Komentarz, red. E. Fojcik-Mastalska, Warszawa 2005.

Smykla B., Prawo bankowe. Komentarz, Warszawa 2011.

Stankowska I., Ustawa o ochronie informacji niejawnych. Komentarz, Warszawa 2014.

Ustawa o kontroli skarbowej. Komentarz, red. K. Kandut, A. Sędkowska, Warszawa 2014.

Walczuk K., Bożek M., Konstytucyjne i ustawowe uwarunkowania organizacji i funkcjonowania Agencji Bezpieczeństwa Wewnętrznego, Siedlce 2015.

Winczorek P., Komentarz do Konstytucji Rzeczypospolitej Polskiej z dnia 2 kwietnia 1997 roku, Warszawa 2008.

Wujczyk M., Prawo pracownika do ochrony prywatności, Warszawa 2012.

Zalewski S., Postępowanie sprawdzające - instrument bezpieczeństwa państwa ujęty $w$ ramach administracyjnych, [w:] Ochrona informacji niejawnych i biznesowych, red. M. Ciecierski, M. Gajos, Katowice 2007.

\title{
POSITION OF PERSONAL SECURITY IN THE SYSTEM FOR PROTECTING CLASSIFIED INFORMATION
}

\section{Summary}

One of the constituents of the state security is protecting information against unauthorized disclosure which would or could be harmful for the Polish state, or would be adverse for its interests, regardless of the form and the way they are expressed. Being classified, such information may be made available only to those who guarantee secrecy, and only to the extent necessary to perform their job or service on a given position, or perform duties entrusted. A screening, being an element of personal security, can prove whether a person guarantees secrecy or not. This procedure is to determine if, after obtaining access to classified information, a person tested would constitute doubts as far as the existence of unauthorized disclosure of classified information is concerned. A security clearance providing access to classified information has to be issued after a thorough examination, and only to the person guaranteeing full secrecy.

Keywords: protecting classified information, personal security, security clearance

\author{
Mirosław Karpiuk \\ m_karpiuk@wp.pl
}

Studia nad Autorytaryzmem i Totalitaryzmem 40, nr 1, 2018

(C) for this edition by CNS 